\title{
Brazilian Peppertree Control ${ }^{1}$
}

\author{
K. T. Gioeli, S. F. Enloe, C. R. Minteer, D. M. Lieurance, and K. A. Langeland ${ }^{2}$
}

Common Name: Brazilian peppertree

Scientific Name: Schinus terebinthifolia

Family Name: Anacardiaceae (cashew or sumac family)

\section{Introduction}

This publication presents management recommendations for Schinus terebinthifolia, the Brazilian peppertree. It contains information about Brazilian peppertree biology, herbicide application techniques, and the status of biological control. The intended audience includes homeowners and land managers primarily in coastal areas of central and south Florida where Brazilian peppertree is prevalent.

\section{General Background}

Many invasive species are harming Florida's natural ecosystems. Brazilian peppertree is one of the worst offenders (Cuda et al. 2006). This plant is encroaching upon nearly all terrestrial ecosystems in central and south Florida and has recently been found in Okaloosa County in the Florida Panhandle. Brazilian peppertree is the most widely distributed and abundant invasive species in the Florida Everglades, occupying 30,379 ha (Rodgers, Pernas, and Hill 2014). Brazilian peppertree is native to Brazil, Argentina, and Paraguay (Langeland et al 2008). It is thought to have been introduced to Florida in the 1840s as an ornamental plant (Figure 1) (Barkley 1944).

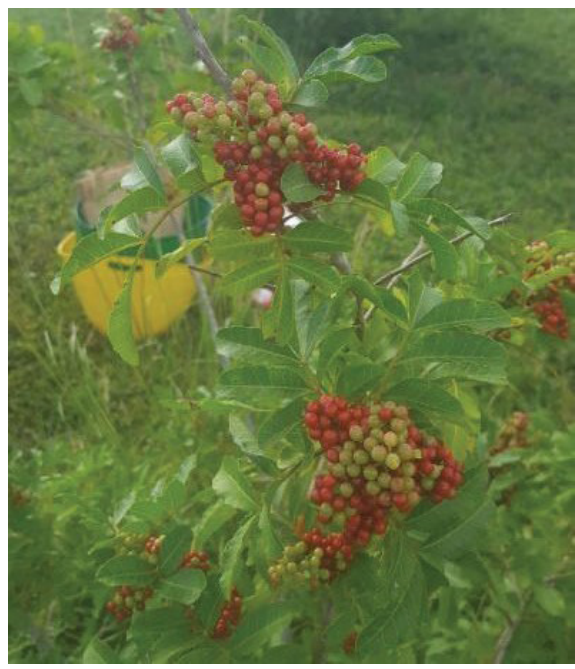

Figure 1. Brazilian peppertree with berries. Credits: C. Minteer, UF/IFAS

\section{UF/IFAS Assessment of Brazilian Peppertree}

The UF/IFAS Assessment of Non-Native Plants in Florida's Natural Areas is a research-based source of information. The UF/IFAS Assessment for Brazilian peppertree can be accessed online at https://assessment.ifas.ufl.edu/ assessments/schinus-terebinthifolia/. Brazilian peppertree is listed on Florida's Noxious Weed List. Inclusion on this regulatory list means "it is unlawful to introduce, multiply, possess, move or release any noxious weed" without a permit in the state of Florida (FDACS 2019a). FDACS defines a noxious weed as:

1. This document is SS-AGR-17, one of a series of the Agronomy Department, UF/IFAS Extension. Original publication date April 1997. Revised November 2018 and November 2021. Visit the EDIS website at https://edis.ifas.ufl.edu for the currently supported version of this publication.

2. K. T. Gioeli, Extension agent IV, UF/IFAS Extension St. Lucie County; S. F. Enloe, professor, Agronomy Department, UF/IFAS Center for Aquatic and Invasive Plants; C. R. Minteer, assistant professor, Entomology and Nematology Department, UF/IFAS Indian River Research and Education Center; D. M. Lieurance, assistant Extension scientist, UF/IFAS Center for Aquatic and Invasive Plants; and K. A. Langeland, professor emeritus, Agronomy Department, UF/IFAS Center for Aquatic and Invasive Plants; UF/IFAS Extension, Gainesville, FL 32611. 
"Any living stage of a parasitic or other plant which may be a serious agricultural threat in Florida; have a negative impact on endangered, threatened, or commercially exploited plant species; or if the plant is a naturalized plant that disrupts naturally occurring native plant communities" (FDACS 2019b).

The Florida Department of Agriculture and Consumer Services (FDACS) oversees this list (including the addition of new species and exemptions for agronomic and horticultural cultivars of listed species). The FDACS Division of Plant Industry (DPI) enforces regulations (inspections and fines) (Lieurance and Gettys 2019). The full list is online at https://www.flrules.org/gateway/ruleNo. asp?id=5B-57.007.

\section{Habitat}

Brazilian peppertree is sensitive to cold temperatures, so it is more abundant in south and coastal Florida and protected areas of central and north Florida. Brazilian peppertree colonizes native communities such as pastures, urban landscapes, pine rocklands, coastal dunes, and more. It has also colonized the margins of roads, rights of way, levees, and canals throughout south and central Florida.

\section{Identification}

The cotyledons (embryonic leaves) are simple; both the apex and the base have an obtuse outline. The margin is generally curved inward on one side. The first true leaves are simple with a toothed margin (Figure 2). The later leaves are compound.
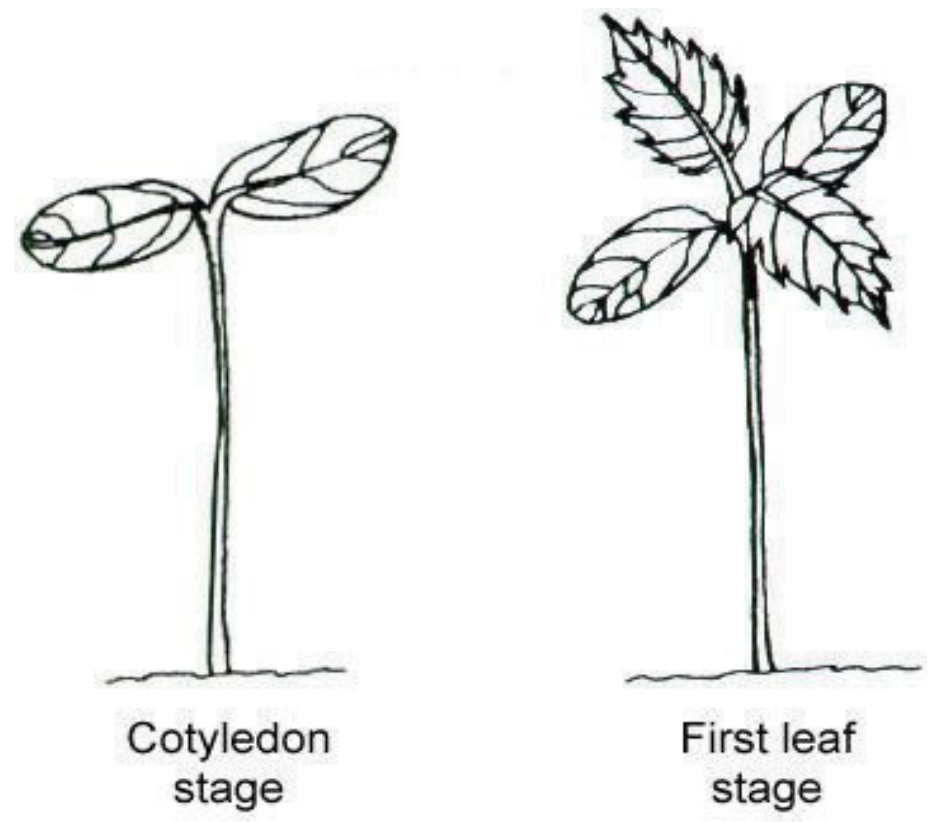

Figure 2. Brazilian peppertree seedlings.

Credits: UF/IFAS Center for Aquatic and Invasive Plants

\section{Mature Plant}

Brazilian peppertree is a shrub or small tree that grows

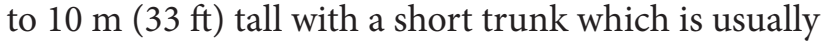
hidden in a dense head of contorted, intertwining branches. The leaves have a reddish and sometimes winged midrib (Figure 3), and three to 13 sessile, oblong or elliptic, finely toothed leaflets, 2.5 to $5 \mathrm{~cm}$ ( 1 to 2 in) long. Leaves smell of turpentine when crushed. The plants are either male and have male flowers (with pollen) or female with flowers that do not produce pollen (Figure 5). The male and female flowers are white (Figure 4) and consist of five parts with male flowers having 10 stamens in two rows of five (Figure 5). Petals are $1.5 \mathrm{~mm}$ (0.6 in) long. The male flowers also have a lobed disc within the stamens. The fruits are found on female plants in clusters. These fruits are glossy, green, and juicy at first. They become bright red upon ripening and grow to $6 \mathrm{~mm}$ (2.4 in) wide. The mature fruit is a small, bright red, spherical drupe (Langeland et al. 2008). Seeds measure $0.3 \mathrm{~mm}$ in diameter and are dark brown in color (UF/IFAS Center for Aquatic and Invasive Plants 2018).

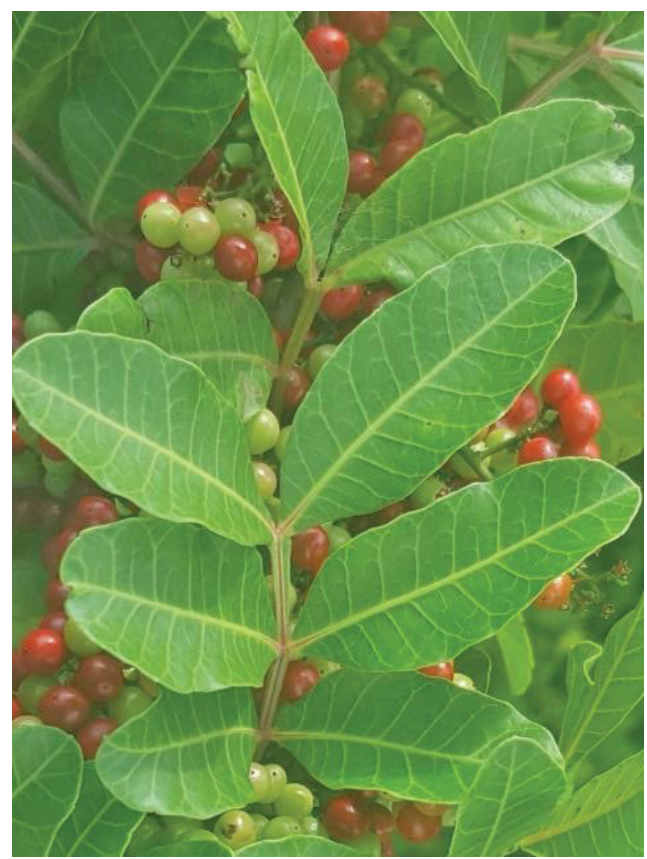

Figure 3. Brazilian peppertree winged midrib. Credits: C. Minteer, UF/IFAS

\section{Biology}

Flowering occurs predominantly from September through November in Florida. Fruits are usually mature by December. Birds and mammals are the primary means of seed dispersal. The removal of the pulp around the seed by the digestive tract of birds increases the seed's germination rate (Dlamini, Zachariades, and Downs 2018). Brazilian peppertree's high seed viability combined with animal dispersal may help explain widespread colonization. 


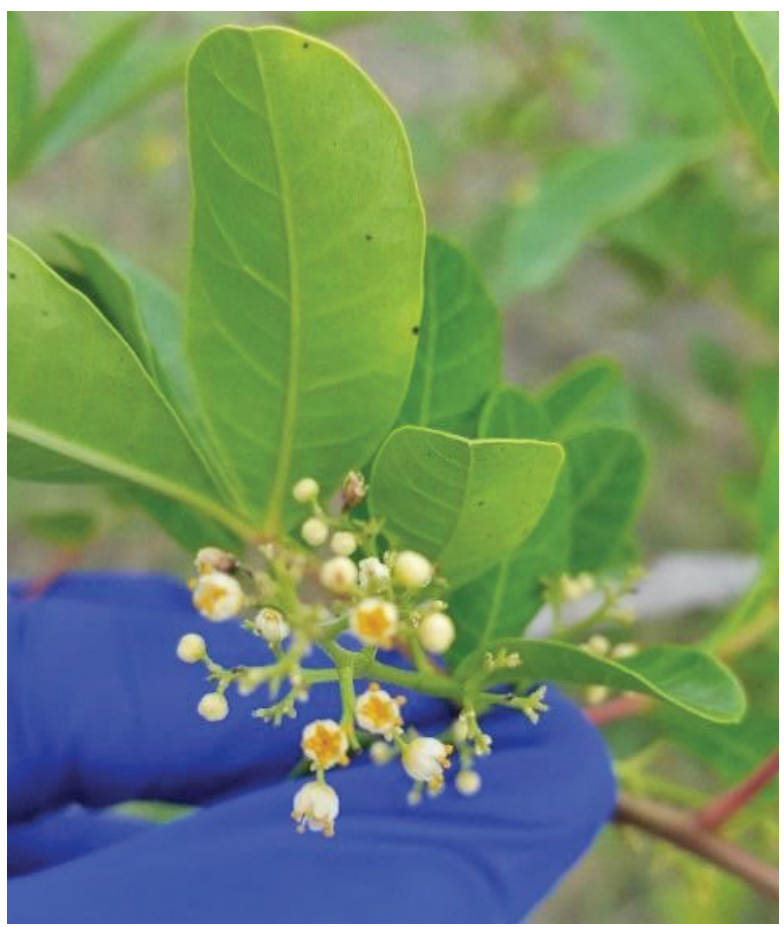

Figure 4. White (male) flowers of the Brazilian peppertree. Credits: C. Minteer, UF/IFAS

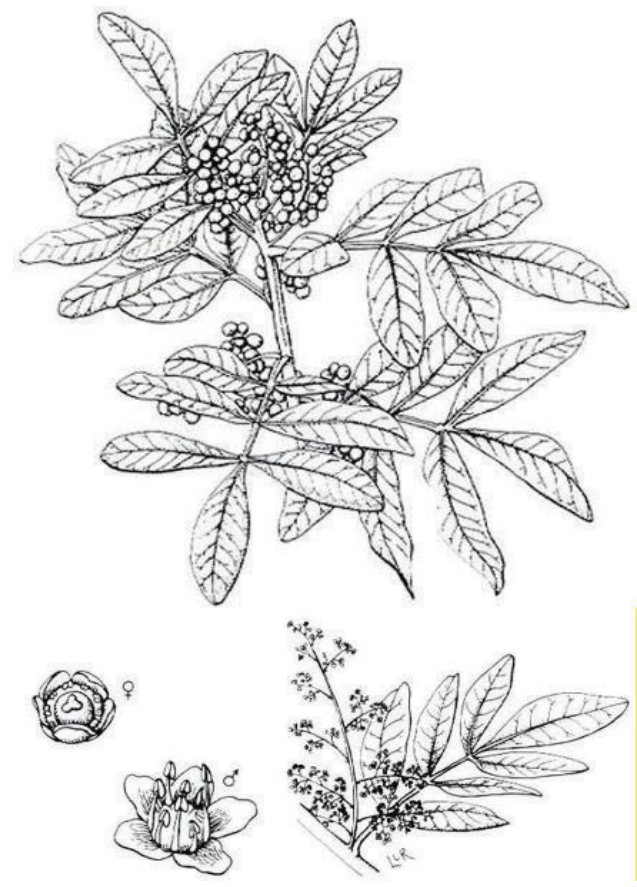

Figure 5. Brazilian peppertree fruiting and flowering. Credits: UF/IFAS Center for Aquatic and Invasive Plants

\section{Chemical Control}

\section{Using Herbicides}

Herbicides that aid in the control of Brazilian peppertrees are available (Table 1). Only herbicides recommended for Brazilian peppertree control should be used. Read the label carefully and follow the instructions; it is illegal to use an herbicide in a manner inconsistent with the label's instructions. For more information on the individual plant treatments listed below, see EDIS publication SS-AGR-260, Herbicide Application Techniques for Woody Plant Control (https://edis.ifas.ufl.edu/ag245).

\section{Cut Stump Application}

Cutting down Brazilian peppertrees and treating the tops of the stumps with herbicide comprise one method of control. A saw should be used to cut the trunk as close to the ground as possible. Within five minutes, an herbicide containing the active ingredient glyphosate or triclopyr should be applied carefully to the thin layer of living tissue, called the cambium, which is just inside the bark of the stump.

The best time to cut Brazilian peppertrees is when they are not fruiting. Seeds in the fruits can produce new Brazilian peppertrees. If fruiting Brazilian peppertrees are cut, care should be taken not to spread the fruits to locations where they might become established.

Caution: Brazilian peppertree produces a sap that may result in contact dermatitis in some people. When cutting trees, avoid the sap if possible. Individuals who are highly sensitive to the sap may also be affected by touching the leaves. Use proper protective gear when cutting the tree and applying the herbicides.

\section{Basal Bark Herbicide Application}

Brazilian peppertrees can be controlled using basal bark herbicide application. In this method, an application of an oil-soluble herbicide product such as triclopyr ester is applied in an oil carrier to the lower part of the trunk in a 12- to 18-inch band around the circumference of the tree. It may take several weeks before the herbicide's effects become apparent. Complete defoliation, a lack of new shoots, and the presence of termites are indicators that the treatment has been successful.

Basal bark treatments are most effective in the fall when Brazilian peppertrees are flowering due to the high level of translocation occurring within the trees. Fruiting occurs during winter, and Brazilian peppertrees that have been treated using a basal bark application may retain their fruit. The herbicide will move downward to the roots with the sap flow. In this situation, the area will need to be checked for seedlings on a regular basis.

\section{Foliar Herbicide Application}

Foliar herbicide application can be used on Brazilian peppertree seedlings and saplings. An herbicide containing 
triclopyr or glyphosate is applied directly to the foliage. Spray to wet, but not to the point of runoff. Good coverage is essential. Although both herbicides translocate throughout the plant, coverage on only one side of a tree with glyphosate or triclopyr will not completely kill it. Keep in mind that foliar applications require considerably more herbicide to control Brazilian peppertree. Take precautions to prevent herbicide drift injury to nearby plants.

\section{Biological Control}

For biological control agents to be approved for release in Florida, scientists must show that those agents are specific to Brazilian peppertree. Two species have been approved for release in Florida: one thrips species and one species of leaf-galling insects in the family Calophyidae. Both the thrips and the leaf gallers feed on new shoots. Releases of the thrips species, Pseudophilothrips ichini, began in Florida in June 2019. A multiagency group of scientists from UF/ IFAS, USDA-ARS, and the Florida Department of Agriculture and Consumer Services Division of Plant Industry are working to rear and release insects on the Florida landscape. The leaf galler, Calophya latiforceps, has not yet been released due to rearing difficulties, but will likely be released in 2022. Both of these species are host-specific to Brazilian peppertree and have been shown to damage the plant in laboratory studies (Prade et al. 2016; Manrique et al. 2014).

For more information, consult the following EDIS publications:

EENY689: Yellow Brazilian Pepper-Tree Leaf Galler (Suggested Common Name) Calophya latiforceps Burckhardt (Insecta: Hemiptera: Calophyidae: Calophyinae)—https:// edis.ifas.ufl.edu/in1186

ENY-820: Classical Biological Control of Brazilian Peppertree (Schinus terebinthifolia) in Florida-https://edis.ifas.ufl. $\mathrm{edu} / \mathrm{in} 114$

EENY270: Brazilian Peppertree Seed Wasp, Megastigmus transvaalensis (Hymenoptera: Torymidae)—https://edis.ifas. ufl.edu/in453

ENY-737: Brazilian Peppertree Thrips Pseudophilothrips ichini (Hood) (Insecta: Thysanoptera: Phlaeothripidae)https://edis.ifas.ufl.edu/publication/in1270

\section{References}

Barkley, F. A. 1944. Schinus L. Brittonia 5:160-98.

Cuda, J. P., A. P. Ferriter, V. Manrique, and J. C. Medal. 2006. Florida's Brazilian Peppertree Management Plan: Recommendations from the Brazilian Peppertree Task Force, $2^{\text {nd }}$ Edition. Florida Exotic Pest Plant Council. http://www. fleppc.org/Manage_Plans/2006BPmanagePlan5.pdf

Dlamini, P., C. Zachariades, and C. Downs. 2018. “The Effect of Frugivorous Birds on Seed Dispersal and Germination of the Invasive Brazilian Pepper Tree (Schinus terebinthifolius) and Indian Laurel (Litsea glutinosa)." S. Afr. J. Bot. 114:61-8.

Langeland, K. A., H. M. Cherry, C. M. McCormick, and K. A. Craddock Burks. 2008. Identification \& Biology of Non-Native Plants in Florida's Natural Areas, $2^{\text {nd }}$ Edition. Gainesville, FL: University of Florida Institute of Food and Agricultural Sciences. Lieurance, D., and L. A. Gettys. 2019. Lost in the Weeds? A Comprehensive Guide to Florida's Many Non-Native Plant Lists. SS-AGR-436. Gainesville: University of Florida Institute of Food and Agricultural Sciences. https://edis.ifas.ufl.edu/publication/AG436

Manrique, V., R. Diaz, L. Erazo, N. Reddi, G. S. Wheeler, D. Williams, and W. A. Overholt. 2014. "Comparison of Two Populations of Pseudophilothrips ichini (Thysanoptera: Phlaeothripidae) As Candidates for Biological Control of the Invasive Weed Schinus terebinthifolia (Sapindales: Anacardiaceae)." Biocontrol Sci. Technol. 24:518-35.

Prade, P., R. Diaz, M. D. Vitorino, J. P. Cuda, P. Kumar, B. Gruber, and W. A. Overholt. 2016. "Galls Induced by Calophya latiforceps (Hemiptera: Calophyidae) Reduce Leaf Performance and Growth of Brazilian Peppertree." Biocontrol Sci. Technol. 26:23-34.

Rodgers, L., T. Pernas, and S. D. Hill. 2014. “Mapping Invasive Plant Distributions in the Florida Everglades Using the Digital Aerial Sketch Mapping Technique." Invasive Plant Science and Management 7:360-74.

UF/IFAS Center for Aquatic and Invasive Plants. 2018. "Schinus terebinthifolia." Plant Directory. Accessed on October 31, 2018. https://plants.ifas.ufl.edu/plant-directory/ schinus-terebinthifolia/\#desc 
Wunderlin, R. P., B. F. Hansen, A. R. Franck, and F. B. Essig. 2021. Atlas of Florida Plants (http://florida.plantatlas.usf.

edu/). [S. M. Landry and K. N. Campbell (application

development), USF Water Institute.] Institute for Systematic

Botany, University of South Florida, Tampa.

Table 1. Herbicides and application methods for Brazilian peppertree control.

\begin{tabular}{|c|c|c|c|}
\hline Active Ingredient $^{1}$ & Application Methods & Mode of Action $^{2}$ & Comments \\
\hline Aminocyclopyrachlor & $\begin{array}{l}\text { Cut stump, basal bark, reduced } \\
\text { hack and squirt }\end{array}$ & HRAC 4Auxin mimic & $\begin{array}{l}\text { For use on noncrop sites only. Primarily } \\
\text { recommended for reduced hack and squirt } \\
\text { technique. Not for use near many desirable } \\
\text { trees and shrubs. }\end{array}$ \\
\hline Glyphosate & Cut stump, foliar & $\begin{array}{l}\text { HRAC 9Inhibition of enolpyruvyl } \\
\text { shikimate phosphate synthase }\end{array}$ & $\begin{array}{l}\text { Use a glyphosate product that contains } \\
41 \% \text { active ingredient or higher. Avoid RTU } \\
\text { (ready-to-use) formulations because they } \\
\text { will not be effective. }\end{array}$ \\
\hline Imazapyr (2 lb/gallon) & $\begin{array}{l}\text { Cut stump, foliar (low volume), } \\
\text { basal bark }\end{array}$ & $\begin{array}{l}\text { HRAC 2Inhibition of acetolactate } \\
\text { synthase }\end{array}$ & $\begin{array}{l}\text { Imazapyr products are generally for } \\
\text { professional use only. Not for use near } \\
\text { desirable trees and shrubs. }\end{array}$ \\
\hline Triclopyr acid & Cut stump, foliar, basal bark & HRAC 4Auxin mimic & $\begin{array}{l}\text { Newer triclopyr formulation with full } \\
\text { aquatic label. }\end{array}$ \\
\hline Triclopyr amine & Cut stump, foliar & HRAC 4Auxin mimic & $\begin{array}{l}\text { Some products available in small } \\
\text { containers from retail garden suppliers. }\end{array}$ \\
\hline Triclopyr ester & Cut stump, foliar, basal bark & HRAC 4Auxin mimic & $\begin{array}{l}\text { Available from agricultural suppliers. Do } \\
\text { not apply directly to water. }\end{array}$ \\
\hline \multicolumn{4}{|c|}{$\begin{array}{l}{ }^{1} \text { Based on the acid. } \\
{ }^{2} \text { HRAC Modes of Action courtesy of https://hracglobal.com/. } \\
\text { For additional information about these herbicide formulations, contact Dr. Stephen Enloe, associate professor with the UF/IFAS Center for } \\
\text { Aquatic and Invasive Plants, sfenloe@ufl.edu. }\end{array}$} \\
\hline
\end{tabular}

